\title{
Flavia Cangià
}

\section{Images of Edo: reinterpreting "Japanese history" and the "buraku" through community-based narratives}

\begin{abstract}
In contemporary Japan, people labeled as "burakumin" ('hamlet people') are commonly described as the descendants of Tokugawa-era outcasts of Japan, who were engaged in special occupations (e.g., leather industry, meat packing, street entertainment, drum making) and compelled to live in separate areas. Despite the heterogeneity of these populations, determination of "buraku origin" (buraku shusshin) has remained fixed over time and is based on one's birth, former or current residence in a buraku, and engagement in the buraku industries. This paper illustrates representations of the buraku through local and community-based initiatives and narratives. It explores the short story "Yomigaetta Kurobe" ('Resurrected Kurobe') by Kawamoto Yoshikazu and the role and activities of the Archives Kinegawa Museum of Education and Leather Industry, located in Kinegawa in Sumida Ward (Tokyo) with a special focus on children's participation. By reinterpreting the "Edo tradition," activists, educators, children, and other individuals in the community transform the "otherness" and blur the boundaries to normalize yet take pride in the "specialness" of the buraku. They do so by drawing on commonplace factors including hard work and the everyday usefulness of objects, as well as special qualities such as skills and craftsmanship.
\end{abstract}

Keywords: buraku, children, Kinegawa, tradition, minority

Flavia Cangià: Institute of Cognitive Sciences and Technologies, the National Research Council CNR, Italy, e-mail: flavia.cangia@gmail.com 
江戸のイメージ :

コミュニティ・ベースドナラティブを基盤とした日本史と部落の再解釈

現在の日本において「部落民」としてレッテルを貼られる人たちは一般徳川に 時代の賤民で、皮革加工、家畜解体業、大道芸人、太鼓職人などの職業に携わ り、特殊な居住地である部落での生活を強いられた人々の子孫であると言われ ている。部落民の多様性にも拘らず、出生地、過去の住居あるいは現在住んで いる元の部落の住所、そしてかつての部落産業での雇用などにより部落出身が 判明するのである。本稿は、ローカルあるいはコミュニティ・ベースド・イニ シャティブやナラティブを通して部落の表象を検討するものである。「よみが えつた黒べえ」と題した短編小説（川元祥一作）を検証し、墨田区「産業・教 育資料室きねがわ」の役割と活動を子供たちの参加という観点から検討する。 江戸文化を再解釈すると活動家、教育者、子供たち、そしてその他のコミュニ ティの住民は部落民の異質性を変化し、境界をぼやけさせて正常化をもたらし、 部落の特殊性にプライドを持つようになるのである。

\section{Introduction}

From the period between the two World Wars and throughout the 1980s, "tradition," and in particular the Edo period (1603-1867) and a number of images related thereto, ${ }^{1,2}$ were adopted as key notions in cultural programs at the local and national level, as well as in commercial media, historical fiction, mass literature, and touristic projects (Robertson 1988; Gluck 1998; Creighton 2009). These notions served the purpose of building, promoting, and strengthening a "national identity" and were supposed to make the Japanese, by virtue of their "Japanese-ness," own certain cultural peculiarities ranging from proprietorship of material culture to linguistic, artistic, religious, and social characteristics. The shifting usages of these notions and associated terms allowed Japanese culture to become linked to employment practices and ideas about "being a good Japanese," that is, hardworking, deferential to authority, dutiful, harmonious, and so forth (McVeigh 2004: 181). Carol Gluck (1993: 70-79) used the term

1 The era is named after the capital city during Tokugawa period, Edo (today Tokyo).

2 Iconic images employed in the "Edo boom" included the tabi bunka ('culture of travel') to locations evoking an Edo-era atmosphere, such as the Edo-Tokyo Museum, the Edo-Tokyo Building Park, and campaigns featuring historic Edo roads (Robertson 1988; Creighton 2009). 
"custodians of the past" to refer to the various agents in this process of nation building and collective construction of "public memory." These include (i) progressive intellectuals who practiced "history as opposition" and opposed any incursion of the prewar past into postwar education and national life; (ii) "conservative intellectuals," including the government, the educational bureaucracy, and politicians, who constructed the establishment history with, at its core, the evocation of a "superior national culture" (Gluck 1993: 72); (iii) "purveyors of the popular past” (e.g., television, newspapers, mass literature, historical fiction), which evoke past individuals and heroes through popular historical imagination and commodified images of history; and (iv) "individual memories," the life stories, the personal pasts of people whose lives were ineluctably intertwined with the events of "history with a capital H” (Gluck 1993: 76).

My interest lies in this fourth category from an anthropological perspective, in particular how historical images are appropriated and transformed in community initiatives at the local level for processes of self-understanding and representation. The paper investigates how the narratives in a buraku district in Tokyo re-appropriate the "Edo tradition" and other tradition-related notions of "Japanese-ness," ${ }^{3}$ and challenge commonplace ideas associated with the buraku (e.g., occupation, residence). In popular discourses, people labeled as burakumin (buraku means 'hamlet' and min 'people') are usually described as the descendants of Tokugawa-era outcasts, people engaged in special occupations (e.g., leather industry, meat packing, street entertainment, drum making) and compelled to live in separate areas. I argue that individuals and networks engaged with the buraku (e.g., activists, performers, teachers, adults and children living in a buraku district and working in buraku occupations) can transform common categorizations in dominant and political discourses (isolation, marginalization, discrimination) and major factors of external categorization (e.g., occupations, residence), and draw on positive principles (e.g., social and economic values, humanistic principles, local and personal attachment, historical images) to validate the buraku in present-day society. As I will show, these are multiple and intersecting principles that question traditional fixed identities (e.g., "Japanese," "buraku") and help position the notion of the "buraku" in a third space of meaning that simultaneously refers to "normality" and "specialness." This third space is not the result of a mere repositioning or inversion of social boundaries, but rather the consequence of a complex process of contestation, expansion, and/or contraction of these boundaries.

3 The Edo period is commonly believed to be the time when "Japanese identity" was consolidated, and the buraku status formalized. 
I draw upon studies that focus on strategies of boundary crossing and blurring through the promotion of non-ethnic principles (Bhabha 1994; Lamont et al. 2002; Wimmer 2008). These strategies shape forms of belonging, and structure social relations and groups by reshaping common standards of categorization and social organization, and undermining the legitimacy of boundaries in favor of other registers of identification. In addition, I wish to lend support to recent research in Japan that examines how a new politics of minorities questions the separation of "minority" and "majority" and renegotiates the role and power of minorities in society (Willis and Murphy-Shigematsu 2008; Graburn et al. 2010), in particular with the participation of children (Stephens 1995; Scourfield et al. 2006; Pache-Huber and Spyrou 2012).

The major historical moments of transformation of the buraku are described in order to identify the key factors that have influenced both the dominant categorization and the minority political agenda. The following sections focus on community-based initiatives in Kinegawa, in particular the short story "Yomigaetta Kurobe" ('Resurrected Kurobe') by Kawamoto Yoshikazu and the role and significance of the Archives Kinegawa Museum of Education and Leather Industry (hereafter Archives Kinegawa).

\subsection{Discourses on the buraku}

"Buraku" is a fluid social construct that encompasses a variety of individuals of different cultural and social backgrounds. The category/image of the buraku has been subject to constant reconfigurations, including transformation of boundaries, industrialization, urbanization, migration, and inter-marriage. Despite the abolition of the status system in 1871, and the implementation of the Law for Special Measures for Dōwa ('assimilation') Projects (Dōwa taisaku jigyō tokubetsu sochi-hō) in 1969, people labeled as burakumin still face discrimination in terms of access to education and housing, discriminatory messages circulating on the Web, as well as background checks conducted by private agencies for employment and marriage. Currently, people residing in buraku districts or labeled as burakumin are mostly engaged in construction work, in the meat or leather industry, and the unskilled labor market (Samuel 2008: 183). Despite the heterogeneity of these populations, determination of buraku origin (buraku shusshin) has remained fixed over time and is based on one's birth, former or current residence in a buraku district, and engagement in buraku industries.

The image of the buraku, as developed by the government and activists' discourses, has also been subjected to various transformations, throughout 
three major historical periods: pre-modern Japan, modern Japan, and post-modern Japan (Mutafchieva 2009). During the pre-modern era (the period preceding the Meiji Restoration), outcast spaces and the variety of individuals and groups living within their boundaries were kept peripheral, physically segregated, and geographically mapped. These people lived in tax-free areas and dealt with the most defiled occupations, ${ }^{4}$ including caretaking of tombs, funeral services, leather tanning and working, butchering, as well as drum and shoe making. All the different categories of occupations and statuses relating to the buraku fell under the two broad categories of kawata/eta ('outcasts') and hinin (lit. 'non-human'). The hinin included criminals, prostitutes, diviners, prison guards, artists, and wandering monks (Koyama 1990; De Vos and Wagatsuma 1966). While some outcasts did not have permanent residence, others resided in settlements on riverbanks, under bridges, and on foothills. Sanjo ('scattered places') - as opposed to honjo ('central/real place') - was one of the numerous terms that referred to these districts in medieval times (Ohnuki-Tierney 1987). Most of the sanjo districts originated as special compounds for ritual performers attached to major ceremonial centers, but animal skinners and leather workers also resided in these areas (Law 1997). Despite the heterogeneity of these settlements and populations, poverty, dirtiness, and separation were the major criteria of negative categorization. However, although segregated, some of these outcast occupations were recognized as important for society at large (Kawamoto 2005; Mutafchieva 2009).

With the Meiji Restoration (in 1871) and the Emancipation Edict (Eta kaihōrei), the eta and hinin became shin-heimin ('new commoners') and were granted the freedom to move and participate in all social activities. However, while these "new commoners" had the legal right to move without restraint, they lost their monopoly on traditional occupations as a source of economic livelihood. The people considered as residents of the previous outcast areas and other disadvantaged groups and individuals were all lumped together into the new category of "buraku." The social stigma and identification was not only reproduced but enforced, in particular by the 1872 law requiring every household to report births, death, marriages, divorces, and criminal convictions (resulting in the koseki family registry system). Historical representations of buraku from the Meiji period onward started to describe these people as the underclass of previous times (Uesugi et al. 1992). The new category of "buraku" is still associated to ideas of poverty, and certain occupational practices and spaces.

4 In feudal times, the taxation system was based on rice yields, which eta/hinin people were not permitted to possess. 
The post-modern period (between the end of the Meiji period through to the post-WWII period) was shaped by the emergence of governmental policies for assimilation and new political actors. ${ }^{5}$ According to the 1965 government report entitled "Fundamental Measures for the Solution of Social and Economic Problems of Dōwa Areas” (Dōwa chiiki ni kansuru shakaiteki oyobi keizaitekisho mondai o kaiketsusuru tame no kihonteki hōsaku), ${ }^{6}$ burakumin "are neither a different race nor a different people, but are without doubt Japanese, both by race and by nationality" (see Wetherall 2008). "Burakumin" were defined as the people who "live together in particular districts and form separate communities," and as “martyrs of industry” (see De Vos and Wagatsuma 1966: 44). The report continues: "History shows that a prime factor barring the path to a rise in social standing and emancipation was that the Dōwa district residents were isolated from the productive process of principal industries in each period of history, and compelled to engage in miscellaneous menial jobs regarded as debased occupations.” In 1969, the Special Measures Law and policies were put in place to facilitate the infrastructural and economic improvement of strictly buraku areas.

During this phase, the constitution of political movements for the burakumin led to the advancement of discourses of resistance and "liberation" (kaihō), as well as "buraku identity" politics rooted in a shared history of marginalization and discrimination as well as geographical birthplace. Since the 1980s, alternative readings of buraku history developed, in particular with a shift from a history of oppression to the valuable social and political role of outcast people (Amos 2011). These readings include the notion of "buraku culture” (buraku no bunka), developed by postwar buraku liberation research institutes in an attempt to positively articulate and reappraise the buraku and strengthen group solidarity (Buraku Mondai Kenkyūjo 1988; Kawamoto 2001; Uramoto 2003). The buraku activist and writer Kawamoto Yoshikazu (2005, 2009), for example, put great emphasis on the role played by the buraku during the Edo period, and describes these occupations as a "recycle system" (risaikuru sōchi) that turned the material of defilement into living and useful sources of everyday life. In addition, he proposed a new branch of study, called "buraku studies" (burakugaku), moving the academic focus beyond the buraku as a discrimination/human rights problem to their positive contributions in history and in the present.

5 The Buraku Liberation League (BLL, Buraku kaihō dōmei) is the main buraku political movement and was founded in 1922 under the name Zenkoku Suiheisha ('National Levelers Association').

6 Buraku areas were renamed dōwa ('assimilation') districts. 
In 2002, the Special Measures were re-examined and subsequently repealed, and in 2007, they ceased to exist altogether. The term "assimilation" (dōwa) was replaced by a new concept ("human right" [jinken]) and a new approach directed toward the recognition of the multicultural character of modern Japan. Despite the heterogeneity of the discourses and approaches, categorization of the buraku still remained linked to ideas of dirtiness, separation, discrimination, and unskilled occupations.

In the 1990s, a special emphasis was put on locality, the relational and social contexts in which actors cooperate and exercise their capacity to influence wider political forces and dynamics. This led to a shift of interest in the community dimension surrounding the buraku experience. This new approach has to be understood within the context of the national measures of community development adopted in the 1960s by the Liberal Democratic Party (e.g., machizukuri 'town-making' programs), as well as the projects sponsored by the Agency for Cultural Affairs (Bunkachō), in which buraku communities looked for a new space of representation. Some of the resulting initiatives revisited these national policies of community development (Mutafchieva 2009), others revisited concepts and images that had been sponsored by nationalism since the 1960s (Cangià 2009). ${ }^{7}$ Several grassroots initiatives (e.g., the monkey dance performance) make use of a great variety of local settings to position buraku cultural expressions within the promotion of cultural activities in local areas advanced by the Agency for Cultural Affairs. ${ }^{8}$ Despite their heterogeneity, they all seem to provide for new readings and a hybrid language constituted of a multiplicity of principles (e.g., everyday life, skills, hometown, tradition). The initiatives discussed in this paper are understood in this context, yet are by no

7 Other examples include the "Osaka Naniwa Human Rights Respect Town Making" and the monkey-training performances of the Monkey Dance Company. The "Osaka Naniwa Human Rights Respect Town Making" was initiated in 2002 in Naniwa district (Osaka) by the BLL with the support of national, municipal, and local administrations. The project includes the Museum of Human Rights Liberty Osaka, the "Road of Human Rights and Taiko (drums)" (an area that extends nearly 500 meters with stone monuments, information boards, and drumshaped benches), and the performances of Ikari ('Anger') drummers at community schools and events.

8 The monkey performance, which was revived in the late 1970 s by a group of artists, ethnologists, and the BLL in Yamaguchi Prefecture, became very popular through the media and entered the official designation of intangible cultural property in 2004. Monkey trainers reach a large audience all over the country by performing in diverse locations (e.g., parks, theatres, schools, television). The Monkey Dance Company (Sarumaiza), in particular, performs the most "traditional" style of training in non-fixed locations (e.g., streets, parks, temples, schools, cultural institutes, local festivals) and thus interacts with the entire population. 
means exhaustive of the multifarious experiences surrounding the buraku. Some of these initiatives and the resulting narratives challenge the commonplace historical portrayal of buraku "otherness" (e.g., dirtiness, separation), through an original interplay of national language and images, minority ideological framework (buraku culture), and more inclusive universal principles (e.g., human rights culture, skills, and socioeconomic standards). Different from before, they make use of a wide set of meanings by drawing on the heterogeneity of the buraku and open the path for multiple registers of identification (e.g., local, national, ethnic, human). In this sense, both the "history of the buraku" and the "national history" become the strategic means of a stronger local engagement and social change and lead to innovative readings of identities.

The context of Kinegawa and its surroundings is most representative of the heterogeneity of the buraku and of the double force informing social actions, including both national and minority institutional agendas and local specificity. The community activities in this context are promoted with the participation of a great variety of individuals, neighbors, supporters of the local Buraku Liberation League (hereafter BLL, Buraku kaihō dōmei), teachers of elementary and junior schools, as well as children and their families. Partly with the support of governmental and municipal bodies and partly on their own, these initiatives revisited concepts and images sponsored by nationalism since the 1960s, including a number of historical images related to the Edo period.

In this paper, I focus on the short story "Yomigaetta Kurobe" ('Resurrected Kurobe') written by Kawamoto Yoshikazu, used for the homonymous educational book (Kawamoto 2008) and how it was interpreted through an exhibition in the Archives Kinegawa Museum and its theater's workshops organized with children. ${ }^{9}$ These are children of various backgrounds (Thai, Bangladeshi, Malaysian, Japanese) who are directly engaged with the buraku issue and/or reside in the community, as well as children who do not reside in the neighborhood but participate in these activities in various ways. Children in this context play a relevant role as political agents in setting adults' institutional agenda (Iwata 1993, 2003; Cangià 2012).

\subsection{Research context and methodology}

This paper draws specifically on the fieldwork conducted in Kinegawa and its surroundings, including participant observation in the Archives Kinegawa

9 The educational book includes the short story, the illustrations by Watanabe Tsumugi, and some comments by the author, children, and BLL supporters. 
Museum and the analysis of exhibition and educational material. Between 2007 and 2009, I conducted around 10 months of multi-site research, traveling throughout the Kinegawa and Naniwa (Osaka) leather towns and accompanying the Monkey Dance Company. During this time, I came into contact with a variety of buraku and non-buraku individuals, traveled with performers, regularly visited museums and districts, participated in community activities, and conducted informal interviews with activists, museum personnel, educators, experts, performers, and other people. I examined exhibits in the museum and conducted a thematic analysis of the children's diaries on display. ${ }^{10}$

Both "buraku" and "burakumin" are terms whose use remains taboo in public life and press coverage. For this reason, I have decided to investigate the production and representation of meanings associated with the buraku by looking at the mise-en-scène of the issue (e.g., performances, exhibits, narratives) in diverse social fields. I decided to focus on two of the most traditional buraku occupations (monkey training and leather tanning) that have followed very diverse paths - one becoming very popular through the media, and the other still associated with the most menial jobs - in order to account for the heterogeneity of buraku occupations.

In November 2007, I visited Kinegawa for the first time, thanks to the advice of some experts in the field, and was invited by one of the museum's founders, Iwata Akio, to the Exhibition of the Special Project of Kinegawa on the occasion of the museum's third anniversary. During the event, I had the opportunity to meet some people from the community, including leather workers, ex-students, and teachers. The contacts established through Professor Kawamoto helped me get in touch with the Monkey Dance Company and other relevant actors during some performances held in Tokyo in July 2008.

During my fieldwork in Kinegawa, I visited the museum each week, visited leather factories when possible, conversed with museum personnel and visitors, activists, educators, people in the community, leather workers, and children, and participated in community gatherings and activities. During our conversations, many people stressed the favorable reputation that leather tanning enjoys in my country, Italy. This facilitated exchanges on the issue of leatherworking, and it helped me establish relations and encourage people to talk about the leather industry in their own town. I was also invited to participate in documentary making in the district, and introduce my own country and travels during

10 These children's "diary notebooks" (seikatsu noto) consist of short compositions written by children between 1964 and 2003 about their daily lives. They were compiled into the collection called "Children of Kinegawa" (Kinegawa no Kodomo) (1959-2003) - and displayed in the last section of the museum as historical documentation. 
children's activities. This also helped me get to know many local people. As I came into contact with individuals, my own "positionality" - that is, the values, subjectivity, and the way researchers identify themselves and engage in conversations/activities - became part of the research and a subject of interest to a number of people organizing the performances. In this regard, my active participation, the occasional inversion of the power-based interviewer-interviewee relationship, as well as the attention that I received as a foreigner in some circumstances created a sort of complicity and collaboration with my informants. In general, my main informants (museum personnel and performers) supported me in selecting the circumstances and ways to introduce myself to members of the community or the audience, at times inviting me to be part of the performance, at times introducing me as a scholar of Japanese culture. The participative characteristic of ethnography was suitable to negotiate these relations: in particular, I adopted a "methodology of slowness" (Kromidas 2012) by letting informants conduct the topic and tempo of conversations, occasionally directing more specific questions to enrich the discussion; and I paid special attention to "complicity" with people (Marcus 1997) by emphasizing reciprocity and collaboration, and recognizing - and playing with - my status as an outsider in the field.

\section{Community-based initiatives in Kinegawa}

Kinegawa (today known as Higashi Sumida) is an important pig leather, oil, and soap producing industrial area in the east of Sumida Ward (Tokyo). The area became a buraku district at the end of the nineteenth century when the city implemented urbanization policies that led to leather factories and workers being relocated from the old buraku district (Asakusa) to the suburban areas of Arakawa and Higashi Sumida. The immigration of "newcomers," intermarriages, and the emigration of buraku residents further modified the demographic composition of the district throughout the twentieth century. Currently, people living, working, or commuting to Higashi Sumida include Koreans, Chinese, South and Southeast Asians (Filipinos, Thais, Malaysians, Bangladeshis), Africans, and Japanese.

Against this backdrop, Kinegawa community-based programs include the Sumida Kodomokai children's organization, school activities, and other community events. Sumida Kodomokai is one of the children organizations (i.e., part of the Kaihō Kodomokai, 'Children's Liberation Society') established by the BLL throughout the country to involve communities in addressing buraku and other forms of discrimination. Children aged between 3 and 13 and their families 
gather on Saturdays in the BLL's building located in a nearby district, and meet with teachers and BLL supporters to cook, draw, play, craft objects, visit factories, and discuss various topics (e.g., daily life, discrimination). Other activities in Kinegawa include exhibitions, educational initiatives, school visits to the surrounding leather factories, and community events.

Like other initiatives of local buraku activism, ${ }^{11}$ community-based activities in Kinegawa and its surroundings are framed within the context of Dōwa education, ${ }^{12}$ national measures of community developments, as well as independent grassroots initiatives. The source of Kinegawa community activism is represented by the past experiences and memories of the former Kinegawa Elementary School, which was opened in the district in 1936 and had been operating as a Dōwa education institute until 2003. The school was closed as a result of increasing discriminatory attacks against the "children of Kinegawa" by children living in the surrounding areas, and the phenomenon known as ekkyo (i.e., not sending one's children to schools where buraku children are enrolled to avoid identification as burakumin). In 2004, after the school's closure, teachers and part of the community decided to maintain the memory of the "children of Kinegawa" and of "Kinegawa education" by founding the Archives Kinegawa Museum on the ground floor of the building. The exhibition includes the history and educational experiences of Kinegawa, with the display of leather tanning machinery, artifacts, pictures (of workers in factories and children crafting leather objects), as well as the children's diaries.

\subsection{The story of "Yomigaetta Kurobe"}

In November 2008, an exhibition of sixteen illustrations portraying the short story of "Yomigaetta Kurobe" was displayed in the Archives Kinegawa Museum (see Figure 1). ${ }^{13}$ The exhibition was the result of a number of cultural activities organized by the community in collaboration with the teachers of a number of elementary and junior schools in the surroundings and the supporters of the Sumida BLL. During the decade between 1996 and 2007, the theatrical workshop organized by the Sumida BLL, teachers, children and their parents, put on a

11 In particular, these activities include "town-making" (machi-zukuri) urban programs and “human rights enlightenment activities” (jinken keihatsu katsudo) (Cangià 2009;

Mutafchieva 2009; Amos 2011).

12 Dōwa education was initiated by the government and the BLL to tackle buraku and other forms of discrimination.

13 These illustrations feature in the educational book Yomigaetta Kurobe (Kawamoto 2008) and were also used for the theatrical plays. 


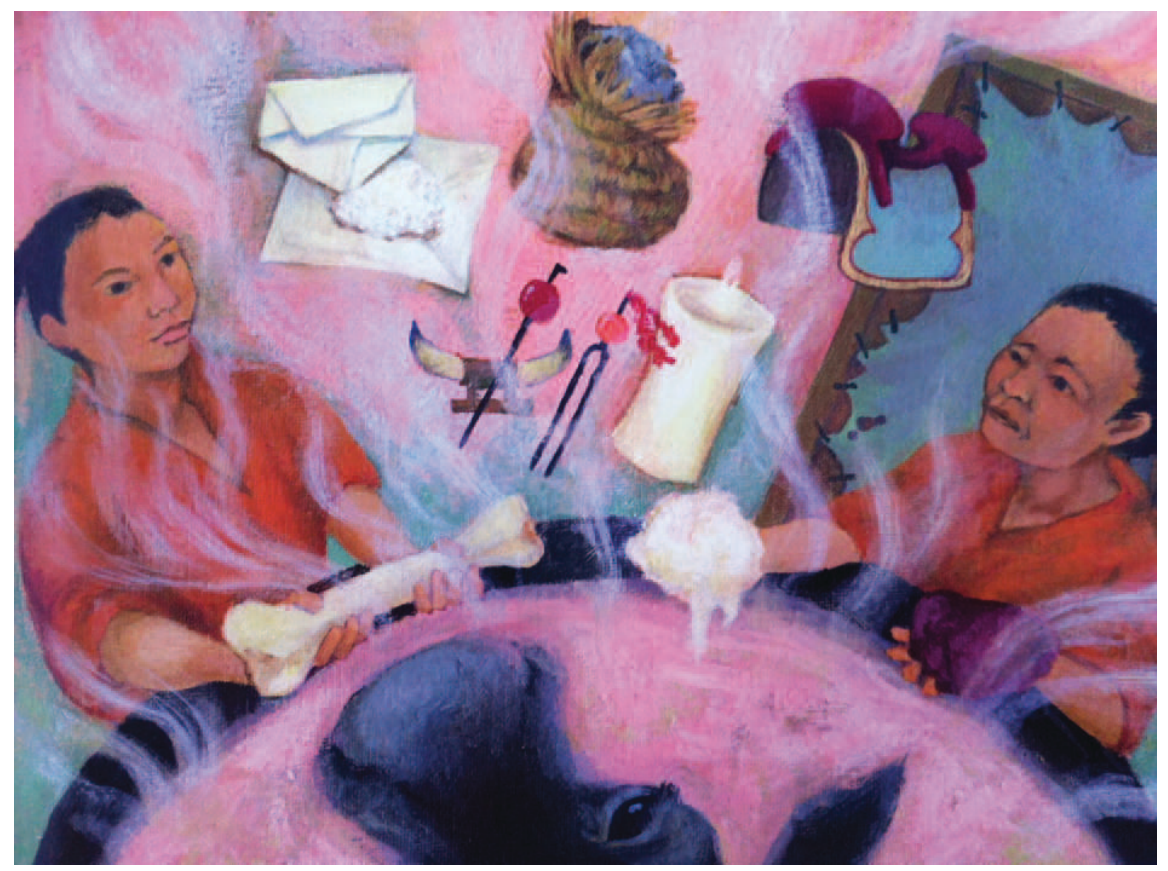

Figure 1: Isuke resurrecting Kurobe the cow into many objects. Drawing by Watanabe Tsumugi.

play based on the short story. This initiative has had a positive impact on the children engaged in the Kodomokai and their peers participating in the theatrical events. As a result of the last representation held in 2007, Watanabe Tsumugi, the mother of a participating child, decided to portray the story as a series of sixteen illustrated scenes. Thanks to the joint collaboration of museum personnel, teachers, parents, and supporters of the BLL, the exhibition was finally staged in the hall adjacent to the main space. The illustrations and texts of the exhibition were also included in an educational book used in the elementary schools in the surrounding area.

The story begins with the introduction of Kurobe, a cow living in a small village. When the cow dies after hard work in the fields for the village, the carcass is brought to the dump, and taken by other villagers who turned it into new objects. The anthropomorphism of objects and animals is a rhetorical device used in the narration to introduce the origins of everyday items and the importance of manufacturing. Kurobe, like objects that appear throughout the story, starts to talk with the villagers about what they want to make out of his carcass: 
"Hello people of the village, where are you bringing me to?"

"As you worked hard for us, we want you to be revived. That's why we bring you to the dump.”

"We take you there so that you can move to the distant land of Buddha."14

Not only objects and animals, but also the process of manufacturing (monozukuri) are employed in the story. This process is described here as a positive expression of gratitude by the villagers for the hard work carried out by the animal, and also by using positive terms such as "the distant land of Buddha." This is the work done by Isuke and his relatives, who work hard, just as Kurobe did in the fields. The process is described as follows:

Isuke cut Kurobe's stomach with a sword.

"Hello, villager. What are doing to me?"

"I am reviving you."

Isuke put the head of Kurobe into a pot.

"Ah, that's a nice head."

"Then, there is the skin. Be careful not to damage it."

Isuke removed the dark fur until he could see the white skin underneath, and Kurobe was impressed:

"Isuke, that's a wonderful skin."

As soon as he cut Kurobe's body, feet, and legs into various pieces, he put everything into the pot.

Now we leave Kurobe into the pot for two days. In the meantime we wash the skin in the river and then we hang it out to dry."

The process and the animal body (skin) are described in a positive way ("that's a wonderful skin"):

"Kurobe has become white grease, meat, and bones."

"Kurobe's skin can become a saddle for samurai horses, the white grease can be used to make candles for illuminating dark nights, the meat can be turned into fertilizers for dry rice fields, and the bones, if delicately ground, can be transformed into medicine."

The hooves and the horn can be used as nice decorations."

"Without wasting a thing, Kurobe is reborn again anew."

"This must be the real Buddha's land," Kurobe thought.

The image of a typical festival (matsuri) represents another means used to depict an anecdote of discrimination and imagine it as occurring in a historical dimension:

14 All quotes from the short story come from Kawamoto (2008). 
Part of Kurobe was turned into a saddle and was brought to a samurai.

One day the following happened: a samurai, riding a horse on Kurobe the saddle, arrived in the town.

That day there was a festival.

In front of a shrine entrance there was a commotion coming from a group of people.

"Why is Isuke from the leather shop here? This is not a place you can come to, get out of here!"

"Right, you make the festival dirty. Get out of here!"

"Why? You yourself often come to the leather shop. We are both human beings."

"Shut up! Get out of here!"

A samurai arrives:

"What is all this fuss about?"

"Samurai! This man is Isuke from the village, from the leather shop. He tries to mingle with us."

"What? This is outrageous! Please punish this rude man."

The samurai took out the sword and pointed it toward Isuke.

Isuke and his family left with tears of humiliation.

The Edo status order is inverted in the narration to imagine social change. Transformation in social relations is described through the intervention of the objects in the scene and their encounters with the humans. Common personages, such as the soldier (samurai), and the objects used in everyday life represent important vehicles in the narrative to make the two levels of the buraku and the non-buraku communicate:

The saddle made out of Kurobe's body spoke: "Why can't Isuke go to the festival?"

The samurai was surprised to hear the saddle speak. "Because if people of humble status got into the shrine, it would become dirty."

"Which people are of humble status?"

"People tanning leather."

"Why?"

"Because they do a dirty job. They remove the skin from animals, so they are humble."

"This is strange - you are riding on a saddle made of leather by Isuke."

The samurai, surprised, jumped from the horse. "Insolence! Do not complain!"

After the festival, the samurai was afraid to mount the horse and gave up. Then he decided to buy candles in the town and study:

Kurobe the candle met Kurobe the saddle. "Candle, nice to see you again!"

"Saddle, you look good."

Then Kurobe the saddle began to tell the story of what had occurred at the festival.

"That's terrible. I cannot believe they treated Isuke so badly." [The candle says this.]

"That's unbelievable. Let's make the samurai think a bit about that."

Then the candle starts to speak to the samurai:

“The candle is useful, isn't it? To study at night when it's dark. Hello, samurai. Did you know that this candle you use now is useful to do things at night?" Kurobe the candle asked. "This useful candle is made from the oil taken from a dead cow." 
The samurai was surprised. "I did not know that the candle was made from the oil of a dead cow. Nevertheless, the people who usually touch these animal carcasses are the lowest in the class system. I will stop studying now and I will quit being a samurai. I want to live a quiet life with friends and the earth, and become a farmer."

The role of the samurai is particularly stressed. As a matter of fact, according to Watanabe, it is the samurai's "social honor" that may help change attitudes toward the buraku. The following development of the story with the samurai becoming a farmer validates the social change and the movement among social statuses:

The samurai quit being a samurai. He immediately moved to the countryside, took a little house nearby Matagoro and, renting a piece of field, began to cultivate it. One day, the samurai realized that the vegetables that he cultivated were quite different from the vegetables cultivated by Matagoro.

“Why are my vegetables so small while Matagoro's are so big? How can you grow such big vegetables?”

"That's because we use different fertilizers. Let's share my fertilizer."

"Thank you!"

The days passed and the samurai's vegetables grew as large as Matagoro's. He was very surprised:

"How do you make these good fertilizers?"

"These are made of the meat taken from dead cows."

"What?" Again the samurai was very surprised.

Finally, the samurai fell sick. Looking at the samurai, Kurobe the fertilizer spoke to Kurobe the medicine:

"The samurai has fallen sick. It would be good for him to take some of you, medicine, to recover."

"Yes, but if he only knew I am made of bones, he would be scared and would not drink me for sure."

"If the samurai does not change his discriminatory attitude, there is nothing left to do."

"That's absolutely right. He will only recover when he realizes that."

Hard work and manufacturing skills (monozukuri) are presented as important traditional values by political ideologies, government reports, and business representatives, and are identified as major factors of Japanese economic success. These standards also provide for an important framework in identity formation for buraku activism, as in the case of the Kinegawa community. In the story, a special emphasis is put on the positive role of the buraku occupations in the everyday life of both the commoners and the samurai. Similarly, the work of the cow is described as important to the villagers (the majority). Kurobe dies of natural causes after the hard work he has done for the villagers. The death, in turn, is portrayed positively as the passage to the "Buddha's land", thanks to Isuke's work (buraku occupations), by two positive characters, Matagoro and 
the cow ("We take you there so that you can move toward the distant land of Buddha"; "This must be the real Buddha's land"). Isuke's work is described as requiring skill, technique, and hard work. During the process, relationships and conversations are depicted between the person and the animal in order to portray the work positively. The value of work is also stressed in the last part when the samurai acknowledges the difficult and hard work in the field.

There are two main elements that help reposition the buraku: the importance of objects in everyday life and the expertise required for the manufacturing process. During my fieldwork, Kinegawa residents, activists, and the children often stressed the strenuous nature of the work as well as the skills of the practitioners working in the leather factories. The work is an important factor identified by the buraku activism to represent social roles in the wider society. Kawamoto Yoshikazu, in this regard, emphasizes the role people like Isuke played and continue to play in enriching our everyday lives. Watanabe, in turn, explains the purpose of the activities depicted in the short story and mostly intended for future generations:

[The story] aims to encourage children to reflect about the fact that despite the discrimination they might face due to the occupation of their parents, these same occupations, like the work of the main character in the story, were historically extremely important, and remain so today. We want to communicate our gratitude to the people working in these occupations and teach children history from another perspective. ${ }^{15}$

\subsection{The Archives Kinegawa Museum of Education and Leather Industry}

The short story "Yomigaetta Kurobe" seems to keep the two realms of the buraku and non-buraku separate in the depiction of objects (buraku) talking to the samurai (non-buraku). However, this exhibition has to be understood in the context of the whole permanent exhibition of Archives Kinegawa and the surrounding activities organized with the participation of people in the neighborhood. The wider context of Kinegawa and its surroundings is important to understand how this "separation" is challenged by a special emphasis on the interplay between different individuals, identities, and experiences that cross the boundaries of the buraku. This interplay leads to a special engagement in and attachment to the "locality," and to multiple fields of exchange (e.g., BLL initiatives involving children from outside the district, joint lessons between

15 From the interviews with Watanabe Tsumugi conducted in Kinegawa in October/November 2008. 


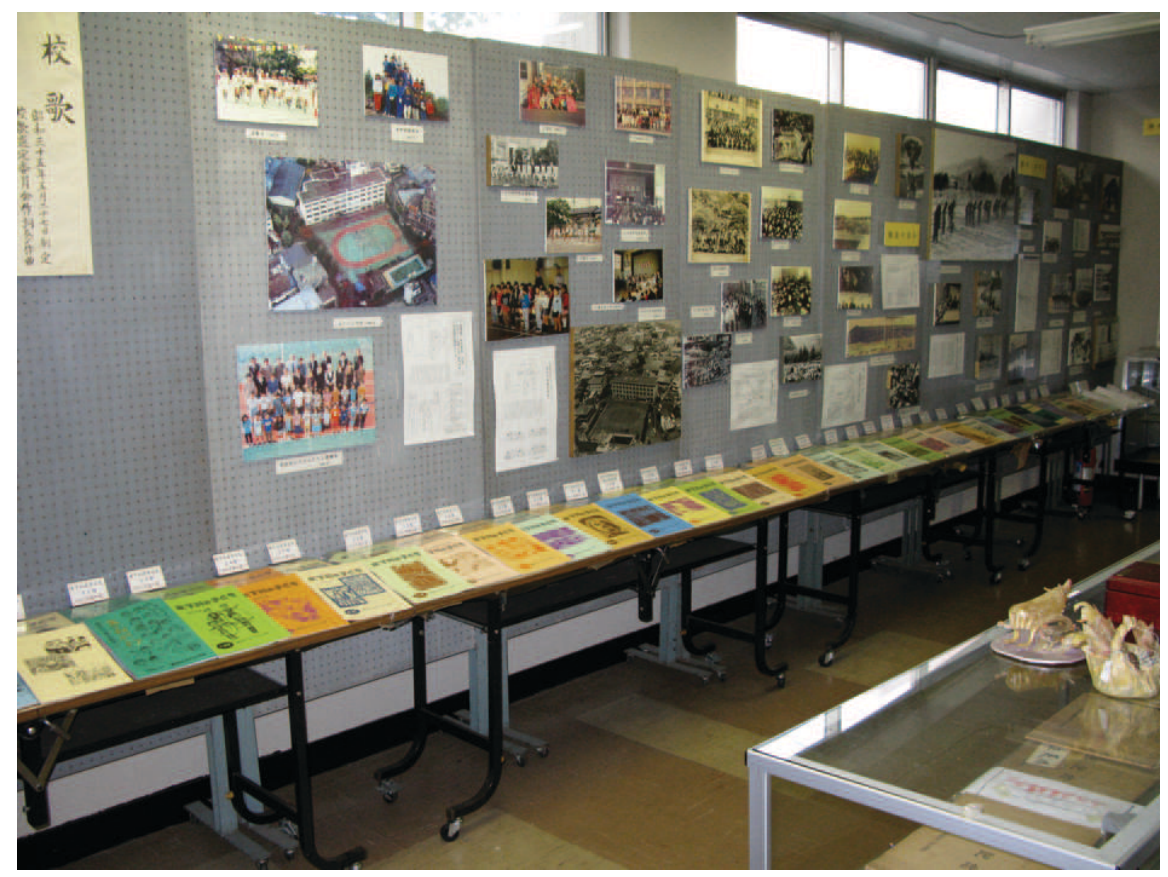

Figure 2: The history of Kinegawa and the children's diaries.

various schools in Sumida Ward, visits to leather factories, and community events).

The museum includes three main thematic areas strengthening this attachment that, in the last few years, has come to expand local participation: ${ }^{16}$ (i) the history of Kinegawa (e.g., diaries, pictures; see Figure 2); (ii) leather tanning, manufacturing techniques, and industrial materials (e.g., leather-made objects, machinery, pictures; see Figure 3); and (iii) the educational project (e.g., handmade items, drawings, pictures; see Figure 4). Narratives in the Archives Kinegawa Museum (e.g., poems and labels) draw special attention to "local attachment" and the "hometown" ( furusato) by employing historical accounts (Kinegawa before and after World War II) and presenting experiences (leather factories in Kinegawa and the relationship with their surroundings). Special emphasis is put on the work of the leather workers: labels and poems in the

16 An example is the influence of the education project of the former Kinegawa Elementary School on other recent surrounding schools in the ward, as well as the organization of joint lessons between different schools, "ethnic" events like ethnic food corners, and fashion shows involving people of different backgrounds. 


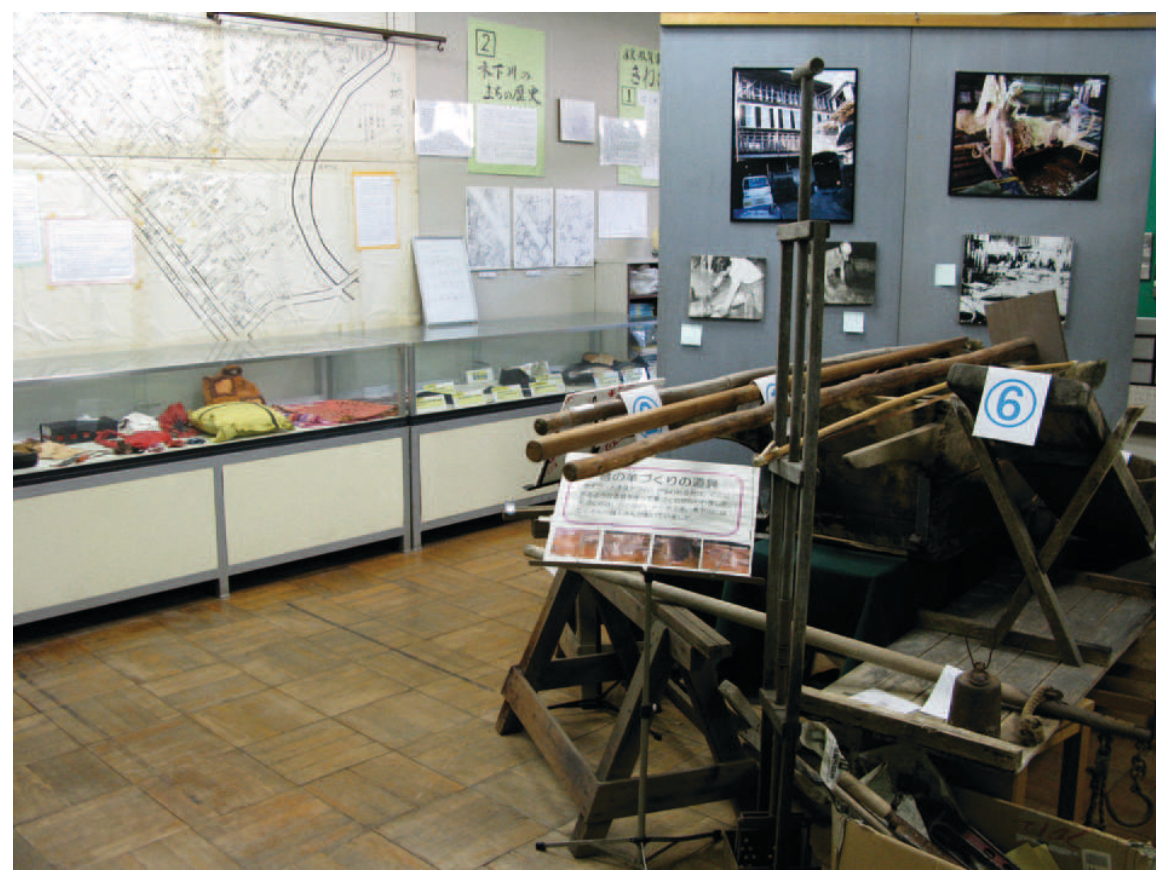

Figure 3: Leather tanning tools and objects.

museum describe physical aspects (e.g., blisters on leatherworkers' hands, forehead sweat, and the blood absorbed into the material) as indicators of the difficulty and skill required to manufacture leather. In addition, the museum follows a modern hands-on approach: contact with the materials and the possibility to touch (and in the case of events organized by museum personnel, the possibility to manufacture) artifacts and objects are emphasized as important moments in which visitors become aware of the positive characteristics of the leather. A glass cabinet is left open to allow visitors to touch sheets of leather of various colors and types. Touching the material and making things are important in the Kinegawa educational strategy, the exhibition, and various community-based events and activities. As in the short story "Yomigaetta Kurobe," the processes and the materials are the main elements on which new forms of representation of the buraku are built. The short story, the educational book, and the whole exhibition in the Archives Kinegawa Museum represent an important framework for children participating. 


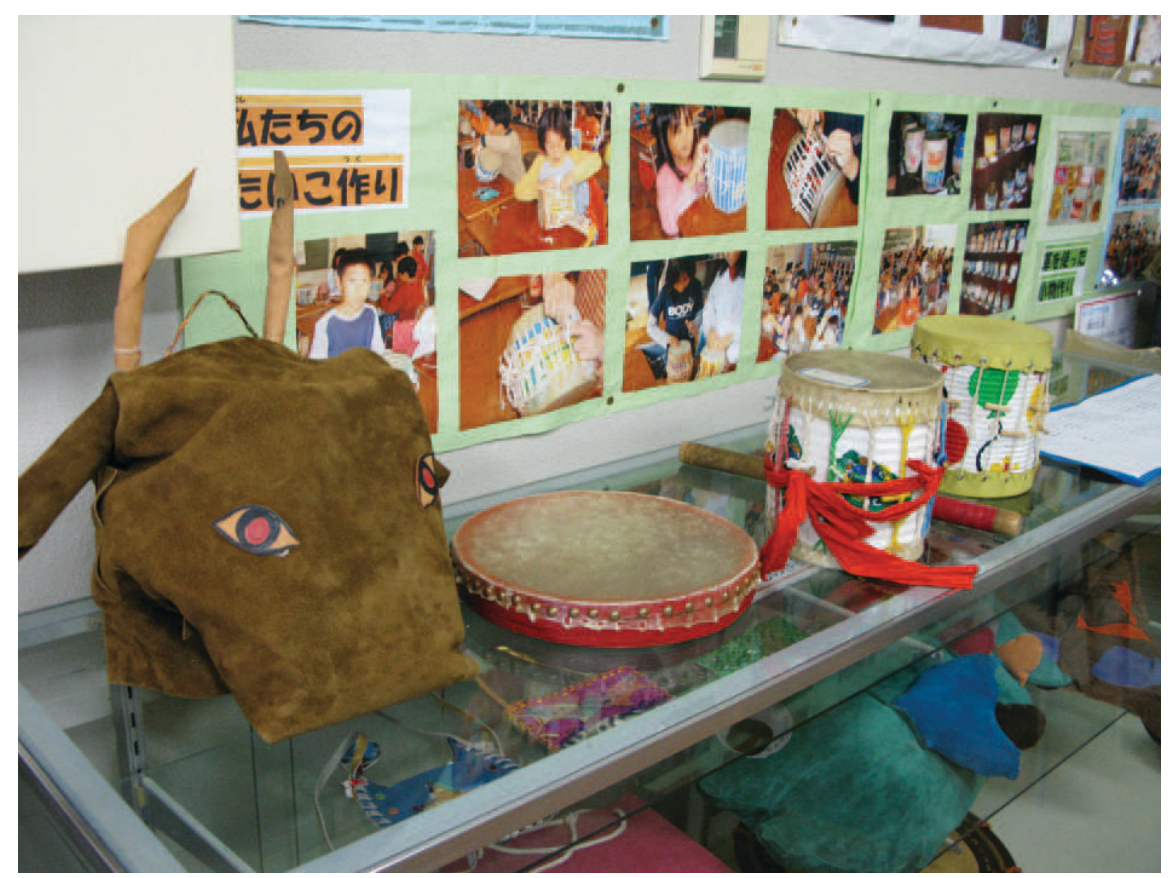

Figure 4: The educational project of Kinegawa Elementary School.

\section{Buraku practices and everyday life objects}

In national discourses, the concept of monozukuri refers to the promotion and preservation of the "Japanese spirit" and skills in manufacturing, designing, and engineering processes. These are promoted through national policies (e.g., through the Ministry of Economy, Trade and Industry) with the objective of passing on Japanese industry and culture to future generations. Similarly, everyday objects produced through monozukuri practices represent important elements that reinforce a national identity for the Japanese people and help vividly maintain traditional culture. These principles also supported activists and educators to mark a third position, in which the buraku are described as "special" and "normal" at the same time. Monozukuri was employed not only in events and the museum's activities, but also in educational and recreational initiatives: children visit leather factories to observe the practice and, at school, they then learn about the use of the leather produced and experience the process by crafting little objects. On the one hand, children/visitors become aware of the use of objects produced by leather workers in the past and in the present, 
as well as the continuity between the buraku products and the non-buraku. On the other hand, through craftwork, they experience the difficulty of the practice. In terms of products (objects), monozukuri serves to underscore the everyday nature of the objects, whereas in terms of process (manufacturing), monozukuri serves to emphasize the specialness and qualities of the practice. In both cases, as in the short story "Yomigaetta Kurobe," the person doing the manufacturing is de-emphasized in favor of skills, procedures, and the resulting products (objects), whereas the objects are the means to tell history and shed new light on the buraku. Furthermore, continuity is established through the employment of these images and the relevance they might have to represent a common past, or in Watanabe's words:

Only the saddle, the candle, the medicine - all the objects that the samurai uses - can communicate and be convincing about the discrimination that these people face. Only these objects can change the samurai's perception [...] These objects are powerful [...] Everyone is aware of the great value of the history of Edo, festivals, samurai, and all the material that we associate with our past. However, the use of candles, fertilizers, and medicine makes it relevant today, and works very well in order to explain to children the great importance of certain occupations in our daily life.

The short story and exhibition of "Yomigaetta Kurobe" proved to be an important work that provides children and visitors with the framework to rethink the buraku issue. Since 1996, children have been involved in the theatrical workshop inspired by the short story. Some of the members participated actively, while other children participated only as audience members or visitors in the museum. Reactions to the images and the short story are very diverse. However, most children seem to actively draw upon the narration's images to reformulate their own opinion about the buraku issue. Unless otherwise noted, the following comments are from the educational book. Some illustrate how children position their parents' work differently from that of the buraku, despite the history of discrimination and commonplace categorization:

(Isuke’s work) is like my father's job of making beautiful leather. (A., first grade)

Isuke works hard to revive Kurobe and turn the cow into candle, saddle, medicine, and fertilizers. So I don't understand why other people would discriminate against him; he is also a human being. (K., fifth grade)

As already mentioned, strengthening awareness of history, work skills, and the role of objects in everyday life is the main strategy to raise awareness of the buraku and make society more inclusive. The following comments illustrate the children's surprise upon discovering the origins of objects and their positive 
view of their parents' work. Continuity between Isuke's work and the parents is common in these narratives:

I was very surprised when I heard that the samurai's saddle is made of cow leather. It is
really interesting. I also thought that the leather that my mom produces is very nice. (R.,
fifth grade) ${ }^{17}$

I didn't know that it is possible to make so many things out of a cow. My dad does this work and produces very nice leather. (M., sixth grade) ${ }^{18}$

In addition, the link between the condition of Isuke in the story and the situation of many people in their present is an important aspect of awareness identified in one of the comments:

Today, there are still people like Isuke who are discriminated against, as well as people like the samurai who discriminate. On a school trip, we visited the place where the animals are dismembered. Many were holding their noses and saying "it stinks" or "the poor animals" [...] but I realized that the people who work in these places do a very hard job every day, and that it is a great thing. For this reason, I want to be more grateful to the people that work for all of us, and to the animals that die. I wish everybody could understand this important work and stop the discrimination. (H., fourth grade)

Children welcome the school visits to leather factories and slaughterhouses as an important occasion to understand the work. These visits are an important part of the Dōwa education programs and buraku activism, namely the use of surrounding facilities to strengthen community relationships and understand the practices.

Negative attributes and master discourses that link the buraku to the "dirtiness" and "smell" of the material and unskilled labor are inverted through the use of historical and commonplace images. A special emphasis is put on the positivity of the source of difference, which is turned into the pleasure of touching the leather, the usefulness of objects in everyday life, and the mastery and skills of the practitioner.

\section{Conclusion}

This paper examined representations of the buraku through reinterpreting history, in particular the Edo era. Local activists concerned with the buraku issue

17 Comment during a school visit to the exhibition in June 2009.

18 From a conversation during a Sumida Kodomokai meeting, June 2008. 
in Japan in various occasions have drawn upon historical accounts relating to buraku occupations: they do so in order to re-position "buraku occupations" by rooting them in social and economic values. ${ }^{19}$ In particular, this paper sought to identify the factors that transform the notion of "buraku" and the multiple ways in which this transformation takes place. Skills, craftsmanship, and hard work, and the everyday usefulness of objects are the means employed to reinterpret history, to cross boundaries, to "normalize" yet pride the "specialness" of the practice.

The representations of the buraku in history do not invert the values attached to the "Japanese", such as hard work, community and family-related values. On the contrary, they draw upon and reinforce these values in order to construct more inclusive identities. "Tradition" and "history" are therefore important vehicles used to position the buraku in a third space in which the "specialness" (skills) and "normality" (social and economic values) of the practices are celebrated simultaneously. The inclusiveness of the category, which includes different backgrounds and experiences, is an important aspect of the initiatives and narratives in Kinegawa. The "specialness" is thus identified not as a marker of buraku distinction, but as a positive and inclusive register of identification that primarily refers to the "practice."

In this context, there is a double influence between the use of "tradition" and "modernity" for social change. The transformation of social relations and the buraku is depicted and imagined as occurring in historical times in order to help children picture another future and think of social changes in their present lives as possible. Children, in turn, draw upon a more comprehensive knowledge about "history" to change perspectives in their present.

\section{Bionote}

Flavia Cangià is Postdoctoral Research Fellow at the Institute of Cognitive Sciences and Technologies, the National Research Council CNR, Italy; Ph.D. in Social Anthropology at the University of Fribourg, Switzerland; research interests: social anthropology, minority and indigenous issues, migration, ethnicity and identity politics, children, Japan, Asia.

19 Like in the case of the "Osaka Naniwa Human Rights Respect Town Making" project in Naniwa, and the exhibition hall in Shinagawa Meat Market and Slaughterhouse, Tokyo. 


\section{References}

Amos, Timothy D. 2011. Embodying difference: The making of burakumin in modern Japan. Honolulu: University of Hawai'i Press Hawai'i.

Bhabha, Homi. 1994. The location of culture. London: Routledge Classics.

Buraku Mondai Kenkyūjo. 1988. Buraku no seikatsushi. Kyoto: Buraku Mondai Kenkyūjo.

Cangià, Flavia. 2009. Performing the "buraku culture." Taiko drums from factory to stage. Phoenix in Domo Foscari, The Online Journal of Oriental Studies 2. 465-473.

http://scriptaweb.eu/Catalogo/phoenix-in-domo-foscari-issue-2 (last accessed 11 February 2010).

Cangià, Flavia. 2012. "Children of Kinegawa" and the transformation of the "buraku identity" in Japan. Childhood 19(3). 360-374.

Creighton, Millie. 2009. The heroic Edo-ic. Travelling the history highway in today's Tokugawa Japan. In Sylvie Guichard-Anguis \& Okpyo Moon (ed.), Japanese tourism and travel culture, 37-75. London: Routledge.

De Vos, George A. \& Hiroshi Wagatsuma. 1966. Japan's invisible race: Caste in culture and personality. Berkeley: University of California Press.

Gluck, Carol. 1993. The past in the present. In Andrew Gordon (ed.), Postwar Japan as history, 64-95. Berkeley: University of California Press.

Gluck, Carol. 1998. The invention of Edo. In Stephen Vlastos (ed.), Mirror of modernity: Invented traditions of modern Japan, 262-284. Berkeley: University of California Press.

Graburn, Nelson, John Ertl \& R. Kenji Tierney (eds.). 2010. Multiculturalism in the new Japan: Crossing boundaries within (Asian Anthropologies 6). New York \& Oxford: Berghahn Books.

Iwata, Akio. 1993. Kinegawa no kodomotachi - chiiki o aishi, hokori ni omou [Children of Kinegawa. Loving the district, feeling proud]. In Higashi Nihon Buraku Kaihō Kenkyūjo (ed.), Higashi Nihon no hisabetsu buraku - genjyō to kadai [The discriminated-against buraku in East Japan - the present condition and the problem], 122-143. Tokyo: Meiseki Shoten.

Iwata, Akio. 2003. Kodomo, chiiki, kyōiku jissen. Kinegawa o chūshin ni [The children, the district, and educational practice. A focus on Kinegawa]. In Sada Ishida (ed.), Ashita o hiraku. Higashi Nihon no buraku-sabetsu mondai kenkyū [Opening up tomorrow. Research on the problem of buraku discrimination of East Japan], 48(131), 5-34. Tokyo: Higashi Nihon Buraku Kaihō Kenkyūjo.

Kawamoto, Yoshikazu. 2001. Nihon bunka no shūen no tēma toshite "burakugaku" o tachiageru [Starting "Buraku Studies" as a marginal topic of Japanese culture]. Tokyo: Rikkyo Daigaku Zengaku Karikyuramu.

Kawamoto, Yoshikazu. 2005. Wajin no bunkaron. Sono kijiku no hakken [Discourse on Japanese culture. The discovery of that axis]. Tokyo: Ochanomizu Shobō.

Kawamoto, Yoshikazu. 2008. Yomigaetta Kurobe. Kinegawa: Kinegawa Kaihō Kodomokai. Kawamoto, Yoshikazu. 2009. Buraku sabetsu no nazo o toku. Kiyome to kegare [Unraveling the mystery of buraku discrimination. Purification and impurity]. Tokyo: Ningen Shuppansha.

Koyama, Eiga. 1990. Dōwa-mondai ni tsuite [On the Dōwa problem]. Tokyo: Shingonshū Satoyamaha Shūmuchō.

Kromidas, Maria. 2012. Affiliation or appropriation? Crossing and the politics of race among children in New York City. Childhood 19(3). 317-331. 
Lamont, Michèle, Ann Morning \& Margarita Mooney. 2002. Particular universalisms: North African immigrants respond to French racism. Ethnic and Racial Studies 25(3). 390-414.

Law, Jane Marie. 1997. Puppets of nostalgia. The life, death, and rebirth of the Japanese Awaji ningyō tradition. Princeton: Princeton University Press.

Marcus, George. 1997. The uses of complicity in the changing mise-en-scène of anthropological fieldwork. Representations 59. 85-108.

McVeigh, Brian. 2004. Nationalisms of Japan: Managing and mystifying identity. Oxford: Rowman \& Littlefield Publishers.

Mutafchieva, Rositsa. 2009. From subnational to micronational: Buraku communities and transformations in identity in modern and contemporary Japan. Montreal: McGill University Ph.D. thesis.

Ohnuki-Tierney, Emiko. 1987. The monkey as mirror. Symbolic transformations in Japanese history and ritual. Princeton: Princeton University Press.

Pache-Huber, Véronique \& Spyros Spyrou. 2012. Special issue: Children’s interethnic relations in everyday life - beyond institutional contexts. Childhood 19(3). 291-301.

Robertson, Jennifer. 1988. Furusato Japan: The culture and politics of nostalgia. International Journal of Politics, Culture, and Society 1(4). 494-518.

Samuel, Yoshiko Yokochi. 2008. The marvelous in the real. Images of burakumin in Nakagami Kenji's Kumano saga. In David Blake Willis \& Stephen Murphy-Shigematsu (eds.), Transcultural Japan. At the borderlands of race, gender and identity, 181-196. London \& New York: Routledge.

Scourfield, Jonathan, Bella Dicks \& Mark Drakeford. 2006. Children, place and identity: Nation and locality in middle childhood. Abingdon: Routledge.

Stephens, Sharon (ed.). 1995. Children and the politics of culture. Princeton, NJ: Princeton University Press.

Uesugi, Satoshi, Teraki Nobuaki \& Nakao Kenji. 1992. Burakushi o yomi-naosu: Buraku no kigen to chüsei hisabetumin no keifu [Rereading buraku history: The origin of the buraku and the genealogy of discriminated communities in medieval history]. Osaka: Kaihō Shuppansha.

Uramoto, Yoshifumi. 2003. Edo, Tokyo no hisabetsu buraku no rekishi: Danzaemon to hisabetsu minshū [The history of the discriminated-against buraku of Edo, Tokyo: Danzaemon and the discriminated-against people]. Tokyo: Akashi Shoten.

Wetherall, William. 2008. The racialization of Japan. In David Blake Willis \& Stephen Murphy-Shigematsu (eds.), Transcultural Japan. At the borderlands of race, gender and identity, 264-281. London: Routledge.

Willis, David Blake \& Stephen Murphy-Shigematsu (eds.). 2008. Transcultural Japan. At the borderlands of race, gender and identity. London \& New York: Routledge.

Wimmer, Andreas. 2008. The making and unmaking of ethnic boundaries: A multilevel process theory. American Journal of Sociology 113(4). 970-1022. 